\title{
MOTIVASI DAN PERSEPSI WISATAWAN MANCANEGARA BERKUNJUNG KE KOTA BUKITTINGGI
}

\author{
Rafidola Mareta Riesa \\ Dosen Prodi Usaha Perjalanan Wisata Politeknik Negeri Padang \\ (Email: rafi_candle@yahoo.co.id )
}

\begin{abstract}
ABSTRAKS
Pariwisata Indonesia yang mempunyai banyak destinasi tujuan wisata membuat wisatawan mancanegara mempunyai motivasi untuk mengunjunginya dan akan mengahasilkan persepsi terhadap destinasi yang telah mereka kunjungi. Salah satu kota yang menjadi destinasi wisatawan mancanegara untuk berwisata di Indonesia adalah Kota Bukittinggi dengan ragam objek wisata yang terdapat didalamnya. Penelitian ini bertujuan untuk mengetahui apa yang menjadi motivasi wisatawan mancanegara berkunjung ke Kota Bukittinggi dan persepsi mereka setelah mengunjungi beberapa objek wisata yang terdapat di Kota Bukittinggi. Hasil penelitian ini diharapkan dapat memperkaya dan melengkapi berbagai kajian ilmiah di bidang pariwisata yang sudah ada. Penelitian kualitatif ini menggunakan metode analisis deskriptif. Pemilihan informan pada penelitian ini menggunakan metode accidental sampling. Pengumpulan data dilakukan dengan metode wawancara terhadap informan yang merupakan wisatawan mancanegara yang sedang berwisata di Kota Bukittinggi. Hasil penelitian dan pembahasan pada tulisan ini, dapat disimpulkan bahwa motivasi wisatawan mancangera yang berkunjung ke Kota Bukittinggi ada (empat) hal yaitu, relaksasi, bermain, belajar dan bertemu teman/ keluarga. Persepsi wisatawan mancanegara yang berkunjung ke Kota Bukittinggi lebih terfokus kepada (lima) hal yaitu aksesibilitas, objek wisata, Interaksi sosial, kebersihan, harga.
\end{abstract}

Kata kunci:

Motivasi, Persepsi, Wisatawan Mancanegara, Kota Bukittinggi.

\begin{abstract}
Indonesia's tourism has a lot of destinations to offer. These destinations would motivate more tourists come to visit Indonesia. After visiting some destinations, the foreign tourists will gain more of perceptions on certain tourism object they visited. One of the destinations for foreign tourists in Indonesia is Bukittinggi, the city that have many choices for tourism object. This research purpose is to acknowledge the motivations of the foreign tourists in visiting Bukittinggi and how was their perceptions on the tourism object. This research is expected to enrich and completes the previous scientific studies in tourism. This qualitative research use descriptive analysis method. The informant were chosen by accidental sampling method. The data collected by interviewing the
\end{abstract}


informants which is the foreign tourists that visited Bukittinggi. The results and discussions on this research concludes that there are four motivations of foreign tourists in visiting Bukittinggi, relaxations, playing at the tourism object, study, to meet friends or relatives. Perception of foreign tourists who visit the city of Bukittinggi is more focused on four things: accessibility, attractions, social interaction, cleanliness, price.

Keywords:

motivation, perception, foreign tourists, bukittinggi city.

\section{PENDAHULUAN}

Sebagai sebuah destinasi wisata, Sumatera Barat mempunyai keunggulan komparatif dalam peta pariwisata Indonesia. Sumatera Barat dikelilingi oleh keindahan panorama alam, keunikan adat istiadat, seni, sejumlah situs sejarah, dan kekayaan alam yang dapat menarik wisatawan datang (Sawirman dan Emrizal, 2008). Salah satu kota yang menarik untuk dikunjungi di Sumatera Barat oleh wisatawan mancanegara adalah Kota Bukiitinggi, khususnya oleh wisatawan mancanegara. Kunjungan wisatawan mancanegara Kota Bukittinggi menunjukkan grafik dan naik turun seperti gambar grafik kunjungan wisatawan mancanegara ke Bukittinggi dari tahun 2009 sampai tahun 2012:

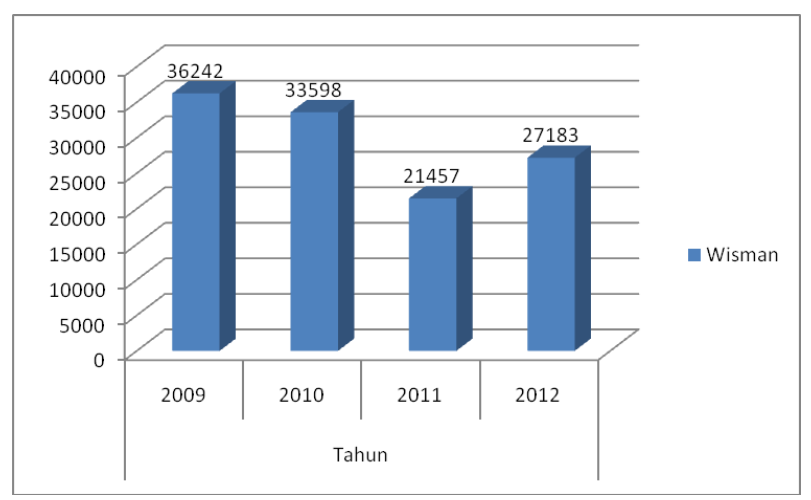

Dari grafik di atas terlihat fluktuasi jumlah wisatawan mancanegara yang berkunjung ke Kota Bukittinggi. Pada tahun 2009 ke 2010 terjadi penurunan jumlah wisatawan mancanegara ke Kota Bukittinggi sekitar $7,3 \%$. Penurunan ini diduga pascagempa yang melanda beberapa wilayah di Sumatera Barat sehingga menyebabkan beberapa objek terkena dampak dan perlu dilakukan perbaikan. Pada tahun 2010 ke tahun 2011 mengalami penurunan hingga $36,2 \%$. Penurunan ini diduga karena kurangnya ketidaksediaan pusat informasi dan rambu-rambu yang jelas sehingga menyulitkan para turis yang datang tanpa pemandu wisata ${ }^{1}$. Penyebab lainnya adalah tidak ada daily program atau kegiatan wisata setiap harinya yang diterapkan sehingga para wisatawan mancanegara merasa bosan jika berlama-lama di Bukittinggi. Pada tahun 2011 ke 2012 jumlah wisatawan mancanegara naik sekitar 26,7\%. Kenaikan ini dipicu oleh semakin membaiknya sarana dan prasarana beberapa objek wisata pascagempa 30 September 2009.

\section{LANDASAN TEORI}

Perjalanan wisata yaitu sebagai suatu perubahan tempat tinggal sementara seseorang di luar tempat tinggalnya karena suatu alasan dan bukan untuk kegiatan menghasilkan upah (Suwantoro, 2004). Pada prinsipnya jika perjalanan itu tidak untuk bersenang-senang (for pleasure), maka perjalanan tersebut tidak bisa dikatakan sebagai suatu perjalanan dalam kategori pariwisata. Kegiatan berwisata tidak lagi dapat diartikan secara sederhana sebagai pengisi waktu luang (leisure) dan mencari kesenangan (pleasure), tetapi untuk mencari pengalaman yang unik dan beragam (Damanik, 2013:156).

Mangkunegara (2003:78) berpendapat bahwa persepsi adalah suatu proses pemberian arti atau makna terhadap lingkungan. Dalam

$1 \quad$ www.harianhaluan.com (Diakses Oktober 2013) 
hal ini persepsi mencakup penafsiran objek, penerimaan stimulus (input), pengorganisasian stimulus, dan penafsiran terhadap stimulus yang telah diorganisasikan dengan cara mempengaruhi perilaku dan pembentukan sikap.

Faktor yang mempengaruhi persepsi wisatawan sebagaimana disebutkan oleh Chi dan Qu (Rajesh, 2013) yang terdiri dari (1) Lingkungan wisata; (2) Wisata alam (3) Hiburan dan peristiwa; (4) Objek wisata bersejarah; (5) Infrastruktur; (6) Aksesibilitas; (7) Relaksasi; (8) Kegiatan di luar ruangan; dan (9) Harga dan nilai,

Motivasi adalah proses yang menyebabkan orang untuk berperilaku seperti yang mereka lakukan. Proses ini dimulai ketika kebutuhan muncul bahwa konsumen ingin memuaskan, sedangkan kebutuhan mengacu pada negara merasa kekurangan (Solomon dan Lepier, 2004 dalam Pratminingsih et al., 2014).

Kebutuhan estetika akhirnya mendorong seseorang untuk menaruh apresiasi pada keindahan alam. Kebutuhan dan motif-motif tersebut dapat diakomodasi melalui kegiatan wisata. (Damanik, 2013). Faktor pendorong seseorang melakukan perjalanan wisata menurut Pitana (2005) yang terdiri dari (1) Escape; (2) Relaxation; (3) Play; (4) Strengthening Family Bond; (5) Prestige; (6) Social Interaction; (7) Romance; (8) Educational opportunity; (9) Self-fulfilment, dan (10) Wish-fulfilment.

\section{METODE PENELITIAN}

Penelitian ini menggunakan metode kualitatif yang berusaha memahami fenomena tentang apa yang dialami subjek penelitian, misalnya perilaku, persepsi, motivasi, tindakan, dan lain-lain, dengan cara mendeskripsikan dalam bentuk kata-kata dan bahasa Moleong (2012:6). Pengumpulan data menggunakan metode wawancara langsung kepada wisatawan mancanegara yang sedang berwisata di Kota Bukittinggi. Data primer diperoleh melalui observasi dan wawancara mendalam (depth interview) terhadap wisatawan mancanegara yang berkungjung ke Bukittinggi. Data sekunder diperoleh melalui studi kepustakaan.

\section{HASIL DAN PEMBAHASAN}

\section{A. Objek Wisata Kota Bukittinggi}

Selain sebagai kota perjuangan, Bukittinggi juga terkenal sebagai kota wisata dengan berbagai macam objeknya. Berikut ini tabel beberapa objek wisata penting yang ada di Kota Bukittinggi:

\begin{tabular}{|l|l|}
\hline No & Nama Objek Wisata \\
\hline 1 & Jam Gadang \\
\hline 2 & Ngarai Sianok \\
\hline 3 & Lobang Jepang/ Goa Jepang \\
\hline 4 & Benteng Fort De Kock \\
\hline 5 & Museum Rumah Adat Baanjuang \\
\hline 6 & Museum Rumah Bung Hatta \\
\hline
\end{tabular}

\section{B. Objek Wisata Pendukung}

Beberapa objek wisata pendukung yang ada di wilayah sekitar Kota Bukittingi seperti tabel dibawah ini:

\begin{tabular}{|l|l|c|c|}
\hline No & Nama Objek Wisata & Lokasi & Jarak Dari Bukittingi \\
\hline 1 & Danau Maninjau & Kab. Agam & $\pm 36 \mathrm{Km}$ \\
\hline 2 & Lembah Harau & Payakumbuh & $\pm 47 \mathrm{Km}$ \\
\hline 3 & Gunung Marapi & Kab. Agam & $\pm 12 \mathrm{Km}$ \\
\hline 4 & $\begin{array}{l}\text { Istano Basa } \\
\text { Pagaruyung }\end{array}$ & Batusangkar & $\pm 44 \mathrm{Km}$ \\
\hline
\end{tabular}

Sumber: olahan penulis (2015)

\section{ANALISIS DAN PEMBAHASAN}

\section{Deskripsi Informan}

Informan dalam penelitian ini adalah wisatawan mancanegara yang pada saat bersamaan sedang berwisata di Kota Bukittinggi. Dalam penelitian ini jumlah wisatawan mancanegara yang bisa dijadikan 
sebagai informan berjumlah 10 orang wisatawan mancanegara. Berikut tabel beberapa data dari wisatawan mancanegara tersebut.

\begin{tabular}{|l|l|l|l|l|l|}
\hline No & Nama & Usia & Kelamin & Asal & Pekerjaan \\
\hline 1 & $\begin{array}{l}\text { Lindsay } \\
\text { Lakin }\end{array}$ & 36 & Perempuan & Inggris & Pengajar \\
\hline 2 & Kaisa & 33 & Perempuan & Polandia & Sukarelawan \\
\hline 3 & $\begin{array}{l}\text { Patrick } \\
\text { Promaey }\end{array}$ & 28 & Laki-Laki & Inggris & Insinyur \\
\hline 4 & Peter & 62 & Laki-Laki & Swiss & $\begin{array}{l}\text { Pensiunan } \\
\text { Bank }\end{array}$ \\
\hline 5 & Yoko Tokida & 25 & Perempuan & Jepang & Travel Agent \\
\hline 6 & Favier Julien & 31 & Laki-Laki & Perancis & Insiyur \\
\hline 7 & Bas Fuetman & 26 & Laki-Laki & Belanda & Pelajar \\
\hline 8 & $\begin{array}{l}\text { Doris de } \\
\text { Kleuver }\end{array}$ & 23 & Laki-Laki & Jerman & Pelajar \\
\hline 9 & $\begin{array}{l}\text { Han } \\
\text { Hererschend }\end{array}$ & 53 & Laki-Laki & Belanda & Insinyur \\
\hline 10 & $\begin{array}{l}\text { Vivianne } \\
\text { Heijkoop }\end{array}$ & 24 & Perempuan & Belanda & Pelajar \\
\hline
\end{tabular}

Sumber: olahan penulis (2015)

\section{Motivasi}

Dalam setiap melakukan perjalanan, wisatawan tentunya didorong oleh motivasi tertentu yang hanya diketahui oleh diri mereka masing-masing. Meskipun dalam berwisata secara bersama-sama, setiap anggota dalam rombongan tersebut tetap memiliki motivasi yang berbeda meski ada di antara mereka yang mempunyai motivasi berwisata yang sama. Motivasi merupakan keadaan dalam diri pribadi seseorang yang mendorong keinginan individu untuk melakukan kegiatan-kegiatan tertentu untuk mencapai tujuan (Dharmnesta dan Handoko, 1982).

Dari penelitian yang telah dilakukan, diketahui beberapa motivasi wisatawan mancanegera berkunjung ke Kota Bukittinggi. Motivasi wisatawan mancanegara yang berkunjung ke Kota Bukittinggi sangat beragam, seperti dipaparkan oleh beberapa informan dalam uraian berikut:

\section{A. Relaksasi}

Relaksasi merupakan kegiatan untuk mengendurkan ketegangan dan kepenatan di dalam diri. Ketegangan dan kepenatan yang muncul di saat menjalani aktivitas seharihari yang menyebabkan timbulnya rasa jenuh dan bosan. Berkunjung ke suatu tempat yang menyenangkan, tidak dapat dipungkiri bisa menghilangkan rasa jenuh dan penat tersebut, seperti melihat keindahan alam, menikmati suasana perdesaan, dan hal lain yang bisa mengurangi kejenuhan dan kebosanan yang ada dalam diri. Berikut paparan dari informan yang datang ke Kota Bukittinggi karena ingin melihat keindahan alam

\section{"I wanna see nature in Bukittinggi and arround." (Informan no 1, 2015) \\ (Saya ingin melihat alam di Bukittinggi dan sekitarnya.}

(Informan no 1, 2015))

"My motivation to come here is want to see the nature of course like Sianok Canyon." (Informan no 5, 2015)

(Motivasi saya datang ke sini tentu saja ingin melihat alam yang ada disini seperti Ngarai Sianok. (Informan no 5, 2015))

"I just back from Mentawai to surf and would go to the Lake Toba. And I think will be good can stay in here for a few days to see the nature." (Informan no 6, 2015)

(Saya baru saja dari Mentawai untuk surfing dan akan pergi ke Danau Toba. Dan saya pikir akan menyenangkan untuk bisa tinggal beberapa hari untuk melihat alam di sini. (Informan no 6, 2015))

Wisatawan mancanegara sangat tertarik untuk melihat keindahan alam di Kota Bukittinggi, salah satunya Ngarai Sianok. Suasana yang tenang dengan udaranya yang sejuk membuat Ngarai Sianok sangat cocok untuk relaksasi melepaskan kepenatan seharihari. Meskipun penyegaran fisik dan mental ini tidak dijelaskan secara detail, di sini bisa dilihat bahwa motivasi wisatawan mancanegara untuk 
melihat keindahan alam masih cenderung menjadi alasan kuat mengapa mereka datang ke Kota Bukittinggi.

\section{B Bermain}

Bermain dalam artian sederhana adalah kegiatan yang dilakukan untuk mencari hiburan dan kesenangan. Kegiatan yang dapat dilakukan baik di dalam maupun di luar rumah. Dalam konteks pariwisata, bermain dapat dikategorikan ke dalam kegiatan yang menyenangkan bagi wisatawan itu sendiri selama berada di suatu destinasi wisata. Kegiatan yang dilakukan oleh wisatawan di daerah tempat mereka berkunjung sangat berbeda-beda. Berikut paparan dari beberapa informan yang datang ke Kota Bukittinggi karena ingin melakukan kegiatan dalam konteks bermain selama berkunjung ke Bukittinggi.

"I want to do volcano trip to Mount Marapi and treeking to Maninjau Lake". (Informan no 2, 2015) (Saya ingin melakukan pendakian ke Gunung Marapi dan trekking ke Danau Maninjau. (Infroman no 2, 2015))

"I just back from the canyon and tomorrow I'll go to a jungle trip to Maninjau" (Informan no 10, 2015)

(Saya baru saja dari ngarai dan besok aku akan menyusuri hutan ke Maninjau. (Informan no 10, 2015))

"I just back from Maninjau for trekking yesterday. It's was wondeful view and trek.(Informan no 7, 2015)

(Saya baru saja kembali dari trekking di Maninjau. Pemandangan dan jalur yang luar biasa. (Informan no 7, 2015))

Keinginan wisatawan mancanegara yang datang ke Kota Bukittinggi untuk bermain seperti halnya melakukan trekking dan hikking, jelas menjadikan hal ini sebagai motivasi yang mendorong wisatawan mancanegara datang ke Kota Bukittinggi. Wisatawan mancanegara yang ingin melakukan kegiatan di alam, biasanya sudah membeli paket perjalanan atau ditawarkan oleh pihak pengelola penginapan yang bekerja sama dengan beberapa travel agent yang ada di Kota Bukittinggi. Paket ini biasanya ditempuh selama 4 hari 3 malam dimana perjalanan menyusuri hutan dari Kota Bukittinggi yang nantinya akan sampai di tepian Danau Maninjau.

\section{Belajar}

Berkunjung ke suatu objek wisata di mana saja sudah barang tentu akan memberikan pelajaran akan hal-hal yang baru bagi wisatawan. Belajar dan mengetahui tentang suatu objek yang sudah berusia lama juga menjadi hal yang menarik bagi wisatawan untuk mereka ketahui karena hal yang baru tersebut tidak akan mereka temui di negara asal mereka. Begitu juga dengan wisatawan mancanegara yang berkunjung ke Kota Bukittinggi. Wisatawan yang datang tidak hanya menghabiskan waktu di suatu objek tanpa hal yang baru yang ingin mereka dapatkan.

\section{"I want to get into the clock tower, but it was not opened at this time. It was like Big Ben in London. It's amazing (Informan no 1, 2015) \\ (Saya tadinya ingin masuk ke dalam menara jam itu, tapi sedang tidak dibuka untuk saat ini. Itu seperti Big Ben yang di London. Sangat menakjubkan. (Informan no 1, 2015))}

"I was very impressed with the clock tower. I've read that the machine is the same as the Big Ben in UK". (Informan no 8, 2015)

(Saya sangat terkesan dengan menara jam. Saya pernah membaca bahwa mesinnya sama dengan Big Ben di UK. (Informan no 8, 2015))

Wisatawan mancanegara yang datang tidak hanya menghabiskan waktu untuk menikmati pemandangan dan keindahan alam Kota Bukittinggi, tetapi juga mempelajari apa yang bisa mereka ambil untuk mejadi tambahan pengetahuan bagi wisatawan mancanegara itu sendiri. Salah satunya adalah melihat menara 
jam yang cukup mencuri perhatian di tengahtengah jantung Kota Bukittinggi, Jam Gadang. Beberapa dari wisatawan mancanegara ada yang mengetahui tentang sejarah Jam Gadang tersebut, seperti contoh wisatawan no 1 dan no 8 yang mengetahui mesin Jam Gadang ini sama dengan mesin Big Ben yang ada di Inggris. Rasa ingin tahu ini membuat mereka ingin mencoba masuk ke dalam menara Jam Gadang.

Kebutuhan akan informasi di suatu objek wisata merupakan hal yang seharusnya diperoleh setiap wisatawan yang berkunjung. Biasanya wisatawan mancanegara menggunakan guide book sebagai pedoman mereka ketika melakukan perjalan wisata. Guide book yang cukup populer di kalangan wisatawan mancanegara adalah Lonely Planet ${ }^{2}$.

Dengan adanya guide book tersebut, wisatawan mancangera setidaknya sudah mengetahui tentang daerah tujuan wisata. Wisatawan juga sudah mengetahui sejarah dari suatu objek wisata yang mereka lihat, seperti sejarah Jam Gadang, Benteng Fort de Kock dan beberapa objek wisata sejarah lainnya yang akan menambah pengetahuan wisatawan itu sendiri.

\section{Bertemu Teman/ Keluarga}

Salah satu motivasi wisatawan melakukan suatu perjalanan wisata adalah untuk bertemu teman atau keluarga yang ada di lain tempat. Beberapa wisatawan mancanegara yang datang ke Kota Bukittinggi juga datang karena akan bertemu teman. Mereka (wisatawan mancanegara-red) diundang datang maupun yang sengaja datang untuk saling mempererat hubungan sosial. Berikut pemaparan dua wisatawan mancanegara yang berkunjung ke

2 http://www.lonelyplanet.com/about/ (Diakses Februari 2016). Loney Planet adalah buku panduan perjalanan wisata yang dbuat oleh pasangan Tony dan Maureen Wheeler yang dulunya mereka samasama seorang backpacker. Setelah mereka menikah dan melakukan beberapa perjalanan, mereka membuat mencatat perjalanan yang akhirnya dibukukan sehingga menjadi reverensi perjalanan wisata bagi traveller.
Kota Bukittinggi yang datang karena ingin bertemu dengan teman atau keluarga.
"I want to meet my friend. He lived here and we had never met again almost 15 years ago". (Informan no 4, 2015)
(Saya ingin bertemu dengan teman baik saya. Dia tinggal di sini dan kami hampir 15 tahun tidak bertemu lagi. (Informan no 4, 2015))
"I've got invitation from my friend. His life here and he want me come here". (Informan no 9, 2015) (Saya diundang teman saya. Dia tinggal disini dan dia ingin saya datang kemari. (Informan no 9,2015$)$ ).

Hubungan kedekatan interpersonal antara sesorang dengan orang lainnya yang sudah dibangun dengan baik akan memunculkan rasa untuk menjaga hubungan tersebut dengan jalan saling mengunjungi satu sama lain. Kedekatan emosinal manusia ini tidak terjadi begitu saja. Hal ini terjadi karena hubungan interpersonal tersebut sudah berlangsung dengan intensitas waktu yang cukup lama antara seseorang dengan orang lain sehingga menimbulkan rasa kasih sayang, saling peduli, dan ingin menjaga hubungan baik tersebut.

\section{Persepsi}

Penilaian akan suatu objek wisata yang datang dari persepsi wisatawan biasanya akan muncul setelah mereka melihat secara langsung dan mengalaminya sendiri di objek wisata tersebut. Hal-hal yang mereka amati dan rasakan selama berada di suatu objek menghasilkan suatu penilaian. Bisa penilaian yang baik, bisa juga penilaian yang buruk. Begitu juga dengan wisatawan mancanegara yang berkunjung ke Kota Bukittinggi. Mereka mempunyai persepsi masing-masing setelah berkunjung beberapa hari di kota ini. 


\section{A. Aksesibilitas}

Wisatawan yang datang ke Kota Bukittinggi dapat menempuh perjalanan dari beberapa kota. Pertama, wisatawan yang mendarat di Bandara International Minangkabau (BIM). Dari BIM ini, wisatawan yang ingin ke Kota Bukittinggi bisa menggunakan beberapa moda transportasi komersial, seperti bus dan mobil travel dengan waktu tempuh \pm 2 jam perjalanan. Kedua, wisatawan yang datang ke Kota Bukittinggi via Medan. Wisatawan mancanegara ini biasanya sudah melakukan perjalanan terlebih dahulu ke Danau Toba, Medan, dan sekitarnya. Pejalanan dari Medan ke Bukittinggi hanya bisa melalui perjalanan darat dan sangat memakan waktu yang cukup lama hingga \pm 16 jam perjalanan.

"Yesteday, I just did a very long overland trip from Lake Toba to Bukittinggi." (Informan no 1, 2015) (Kemarin, saya baru saja melakukan perjalanan darat yang sangat panjang dari Danau Toba ke Bukittinggi. (Informan no 1, 2015))

"I landed in Padang and was picked up by my friend. I think the access road is quite good al though winding and several road uphill." (Informan no 9, 2015)

(Saya mendarat di Padang dan dijemput oleh teman saya. Saya pikir jalan akses cukup baik meskipun berbelok-belok dan beberapa jalan menanjak. (Informan no 9, 2015))

"The road is quite good from the airport to Bukittinggi. Although many squiggly and occasional uphill with a natural landscapes. (Informan no 3, 2015)

(Jalannya cukup baik dari bandara ke Bukittinggi. walaupun banyak yang berbelokbelok dan sesekali menanjak. Dengan pemandangan alam yang sangat alami. (Informan no 3, 2015))

Aksesibilitas menuju suatu kota yang menjadi destinasi wisata merupakan salah satu bagian penting pendukung bagi wisatawan untuk datang ke suatu destinasi wisata. Wisatawan mancanegara yang baru pertama kali berkunjung ke Kota Bukittinggi melalui jalur darat baik dari Kota Medan maupun yang datang dari Kota Padang, akan disuguhkan akses jalan yang cukup berbeda. Seperti yang telah diterangkan pada bab sebelumnya ${ }^{3}$, terdapat 2 (dua) perbedaan jarak dan waktu bagi wisatawan mancanegara untuk bisa menuju Kota Bukittinggi, baik wisatawan mancanegara yang datang dari Kota Medan maupun wisatawan mancanegara yang datang dari Kota Padang.

\section{B. Obyek Wisata}

Beberapa objek wisata yang ada di Kota Bukittinggi seperti Ngarai Sianok, Goa Jepang, Jam Gadang, Benteng Fort de Kock dan lainnya memang masih menjadi tujuan utama untuk didatangi oleh wisatawan, baik wisatawan domestik maupun wisatawan mancanegara. Hal tersebut tidak lepas dari baiknya pengelola menjaga dan merawat objek wisata sehingga apa yang dilihat dan dirasakan oleh wisatawan selama berada di objek wisata cukup untuk membuat wisatawan merasa puas.

"I've been go to canyon, has good view. But I don't have many time today for the others object. May be tomorrow".

(Informan no 1, 2015)

(Saya sudah pergi ke Ngarai. Pemandangan yang bagus. Tapi untuk hari ini saya tidak punya banyak waktu untuk ke objek yang lainnya, mungkin besok saya bisa ke sana. (Informan no 1, 2015))

"I like go to the canyon with awesome landscape. But for the tunnel I think just like a tunnel normaly". (Informan no 2, 2015)

(Saya suka pergi ke Ngarai dengan pemandangan yang luar biasa. Tapi untuk terowongan saya pikir hanya seperti terowongan biasa.

(Informan no 2, 2015))

Lihat halaman 32 
"Sianok canyon has a nice view. I take some picture there. Japanese Tunnel just like a tunnel. No more information there. (Informan no 3, 2015)

(Ngarai Sianok memiliki pemandangan yang indah. Saya mengambil beberapa gambar di sana. Terowongan Jepang hanya seperti sebuah terowongan saja. Tidak ada informasi lebih lanjut di sana. (Informan no 3, 2015))

"I think for the tunnel must be improved to amenities and lots of graffiti". (Informan no 8, 2015)

(Saya pikir untuk terowongan [Lobang Jepang] harus ditambahkan lagi sarana pendukung. Dan banyak sekali coretan di sana.

(Informan no 8, 2015))

Persepsi yang muncul dari wisatawan mancanegara setelah melihat beberapa objek wisata yang mereka kunjungi merupakan salah satu bentuk pandangan mereka yang terbentuk dari apa yang mereka lihat dan rasakan selama berada di objek wisata tersebut. Untuk Ngarai Sianok banyak wisatawan yang merasa puas setelah mereka datang dan menikmati pemandangan yang ada. Seperti pemaparan informan no 1 saat datang ke Ngarai Sianok. Dia mengatakan Ngarai Sianok mempunyai pemandangan yang sangat bagus. Hanya saja, untuk hari itu dia tidak punya banyak waktu untuk mendatangi objek wisata yang lainnya di sekitar Kota Bukittinggi dan akan melanjutkannya esok harinya. Selanjutnya informan no 2 mengatakan bahwa dia sangat suka saat berada di Ngarai Sianok dengan hamparan pemandangan yang menurut dia sangat luar biasa. Berikutnya informan no 3 mengatakan Ngarai Sianok memiliki pemandangan yang sangat indah. Dia juga mengabadikan beberapa gambar pemandangan sekitar Ngarai Sianok dengan kamera yang dia bawa

\section{Interaksi Sosial}

Salah satu yang tidak bisa lepas dari sebuah perjalanan yang dilakukan oleh wisatawan adalah interaksi. Interaksi ini terjadi dengan sendirinya disaat wisatawan membutuhkan informasi dari masyarakat lokal tentang halhal yang ingin mereka ketahui. Misalnya saat wisatawan ingin menanyakan alamat hotel, restoran, atau akses menuju objek wisata yang akan mereka kunjungi. Interaksi wisatawan juga bisa terjadi di saat mereka disapa oleh penduduk.

"Good people, so warm and friendly. I met so many
students say 'hello' and some of them try to practice
English with me" (Informan no 1, 2015)
(Orang-orangnya baik dan begitu hangat dan
ramah. Saya bertemu dengan banyak anak
sekolah yang menyapa 'hello' dan beberapa
dari mereka berbicara dengan saya dalam
bahasa Inggris. (Informan no 1, 2015))

"Good. Nice local people here.. Many kids says 'hello $\mathrm{Mr}$ ' to me and shaking hands." (Informan no 3, 2015)

(Baik. Penduduk lokalnya baik-baik. Banyak anak-anak menyapa 'hello $\mathrm{Mr}^{\prime}$ kepada saya dan ada juga yang mengajak bersalaman. (Informan no 3, 2015))

"Good. Very friendly and I got some a new friends here..". (Informan no 8, 2015)

(Baik. Sangat ramah dan saya mendapatkan teman baru disini. (Informan no 8, 2015))

"Good people I think, but I am not too much communication with local people." (Informan no 9, 2015)

(Saya pikir masyarakatnya baik, tapi saya tidak terlalu banyak berkomunikasi dengan mereka. (Informan no 9, 2015))

Interaksi sosial merupakan hubungan sosial yang dinamis menyangkut hubungan antara orang perorangan, antara kelompok-kelompok manusia, maupun antara orang perorangan dengan kelompok manusia (Soekanto, 2006:62). Oleh karena itu, sebagai salah satu destinasi wisata yang dikunjungi, mau tidak mau masyarakat Kota Bukittinggi akan berinteraksi 
sosial dengan wisatawan mancanegara, baik secara langsung maupun tidak.

\section{Kebersihan}

Kebersihan merupakan salah satu hal yang membuat wisatawan ingin mengunjungi suatu tempat wisata. Berikut beberapa informasi dari wisatawan mancanegara yang mendatangi objek wisata di sekitar Kota Bukittinggi.

"I saw still a lot of trash in some object that I was visited".

(Informan no 4, 2015)

(Saya melihat masih banyak sampah di beberapa objek wisata yang sudah saya datangi. (Informan no 4, 2015))

"At the canyon, I saw a lot of trash and when I go to the tunnel so many grafitty on the wall of the Japannes Tunnel". (Informan no 7, 2015)

"Di Ngarai saya lihat banyak sampah dan ketika saya masuk ke dalam Lobang Jepang banyak coretan di beberapa dinding nya. (Informan no 7, 2015))

"A lot of garbage around the Jam Gadang." (Informan no 10, 2015)

(Banyak sampah di sekitar Jam Gadang. (Informan no 10, 2015))

Tanggapan yang kurang baik dari wisatawan mancanegara tentang kebersihan pada destinasi wisata Ngarai Sianok, Lobang Jepang, dan Jam Gadang di Kota Bukittinggi, pada titik tertentu akan mengakibatkan menurunnya citra destinasi wisata di Kota Bukittinggi. Dalam lingkungan wisata hendaknya suatu objek tertata rapi dan bersih sehingga menimbulkan rasa nyaman bagi wisatawan yang datang berkunjung. Dengan kata lain kebersihan menjadi aspek penting yang harus diperhatikan dalam pengelolaan destinasi wisata. Informan no 4 yang merupakan wisatawan asal Swiss mengatakan bahwa saat mengunjungi Ngarai Sianok, wisatawan ini melihat banyak sampah di objek wisata tersebut. Hal ini membuat dirinya sangat terkejut karena menurut wisatawan ini suatu objek wisata seharusnya bersih sehingga membuat nyaman ketika dikunjungi.

\section{E. Harga}

Salah satu hal yang selalu menjadi perbandingan dalam setiap perjalanan wisata adalah harga. Meski tidak semua wisatawan mempersoalkan harga, tetapi hal ini juga menjadi tolok ukur dari kedatangan wisatawan ke daerah tujuan wisata. Misalkan di suatu daerah tujuan wisata terkenal dengan harganya yang mahal, maka ini bisa menjadi bahan pertimbangan oleh calon wisatawan untuk datang karena mereka harus mengeluarkan biaya yang relatif lebih, begitu juga sebaliknya. Berikut beberapa tanggapan wisatawan mancanegara mengenai harga selama mereka berkunjung ke Kota Bukittinggi.

"For the hotel and foods the prices is not too expensive" (Informan no 1, 2015)

(Untuk hotel dan makanan, harganya tidak terlalu mahal. (Informan no 1, 2015)

"I think the prices is very good. Not too expensive" (Informan no 2, 2015)

(Saya pikir harganya sangat bagus. Tidak terlalu mahal. (Informan no 2, 2015)

"I think the prices is normaly. Not too expensive for the hotel or restaurant" (Informan no 3, 2015) (Saya pikir harganya normal. Untuk hotel dan makan tidak terlalu mahal. (Informan no 3, 2015)

"The prices is fair, not too expensive". (Informan no 4, 2015)

(Harganya sangat masuk akal. Tidak terlalu mahal. (Informan no 4, 2015)

"It's normal prices I think, not too expensive". (Informan no 8, 2015)

(Sangat normal, tidak terlalu mahal. (Informan no 8,2015 ) 
Persepsi wisatawan mancanegara mengatakan bahwa harga yang mereka keluarkan untuk penginapan, makan, dan lainnya relatif murah dan tidak terlalu mahal. Harga yang murah dengan pelayanan yang baik sudah jelas akan mempengaruhi pandangan seorang calon wisatawan untuk melakukan perjalanan. Perbandingan harga yang mereka lakukan untuk pergi ke satu destinasi dengan destinasi lainnya terjadi karena adanya informasi atau referensi mengenai harga di suatu destinasi wisata yang akan mereka kunjungi. Referensi harga di suatu destinasi ini bisa saja mereka dapatkan dari informasi mulut ke mulut sesama traveller yang kebetulan sudah pernah mengunjungi destinasi itu telebih dahulu atau dari tulisan wisatawan di media sosial baik itu dari blog pribadi atau media online lainnya.

\section{KESIMPULAN DAN REKOMENDASI}

\section{A. Kesimpulan}

Dari hasil penelitian dan pembahasan pada tulisan ini, dapat disimpulkan bahwa motivasi wisatawan mancangera yang berkunjung ke Kota Bukittinggi ada 4 (empat) hal, yaitu (1) relaksasi; (2) bermain; (3) belajar; dan (4) bertemu teman/keluarga. Keindahan alam yang terdapat di Kota Bukittinggi masih menjadi magnet kuat dalam menarik minat wisatawan mancanegara untuk datang dan melihat secara langsung. Hal ini juga didukung oleh keberadaan beberapa objek wisata yang terletak ditidak jauh dari Kota Bukittinggi. Beberapa kegiatan alam yang bisa dilakukan juga menjadi penarik minat wisatawan mancanegara untuk datang.

Persepsi wisatawan mancanegara lebih tertuju kepada lima hal. Pertama, aksesibilitas. Wisatawan mancanegera pada hal ini memiliki persepsi yang sedikit berbeda. Hal ini dikarenakan jalur kedatangan wisatawan mancanegara yang berbeda-beda. Seperti beberapa wisatawan mancanegara yang datang ke Kota Bukittinggi melalui jalan darat dari
Kota Medan. Perjalanan ini akan menempuh jarak \pm 669 kilometer atau \pm 16 jam. Wisatawan yang datang melalui Bandara Internasional Minangkabau hanya membutuhkan waktu tempuh $\pm 1,5$ sampai 2 jam perjalanan. Kedua, objek wisata. Wisatawan mancanegara mempunyai persepsi yang sama tentang objek wisata di Kota Bukittinggi terutama Ngarai Sianok. Wisatawan mancanegara merasa senang setelah datang dan melihat keindahan panorama Ngarai Sianok. Wisatawan mancanegara juga bisa berfoto mengabadikan keindahan alam Ngarai Sianok dengan latar belakang pemandangan yang indah. Hanya saja, untuk objek wisata Lobang Jepang, wisatawan mancanegara tidak merasakan hal yang istimewa setelah masuk ke dalam lorong-lorong di dalamnya karena menurut mereka hanya seperti labirin kosong yang tidak ada informasinya. Ketiga, interaksi sosial. Wisatawan mancanegara merasakan interaksi sosial yang sangat bagus selama berada di Kota Bukittinggi. Komunikasi mereka dengan masyarakat lokal cukup bagus sehingga tidak ada kendala selama berwisata. Keempat, kebersihan. Untuk kebersihan, wisatawan mancanegara mempunyai persepsi yang sama, yaitu mereka sangat mengeluhkan kurang bersihnya objek wisata di Kota Bukittinggi. Contoh di beberapa bagian Ngarai Sianok dan di sekitar Jam Gadang. Wisatawan mancanegara melihat masyarakat yang datang ke objek wisata dengan mudahnya membuang sampah di sembarang tempat. Padahal, di beberapa titik sudah tersedia tempat sampah. Hal ini membuat persepsi wisatawan mancanegara mengenai kebersihan sangat buruk. Kelima, harga. Wisatawan mancanegara semua setuju bahwa mereka tidak ada permasalahan dengan harga yang ada pada setiap transaksi mereka, baik untuk penginapan, restoran, toko oleholeh, dan lain-lain. Wisatawan mancanegara sepakat harga masih normal dan tidak terlalu mahal. 


\section{B Rekomendasi}

Berdasarkan kesimpulan yang diperoleh dalam penelitian ini, maka peneliti memberikan beberapa rekomendasi dan saran sebagai berikut.

1. Dinas Pariwisata bekerja sama dengan Pengelola Ngarai Sianok dan Lobang Jepang harus lebih meningkatkan sarana dan prasarana di kedua objek wisata ini, seperti tempat sampah di beberapa titik di Ngarai Sianok dan membenahi interior Lobang Jepang sebaik mungkin agar menjadi lebih menarik untuk dikunjungi wisatawan mancanegara.

2. Pemerintah Kota Bukittinggi perlu mempercepat pengembangan objek wisata yang memiliki potensi yang lebih menarik minat berkunjung wisatawan mancanegara seperti Rumah Baanjuang, Museum Bung Hatta, dan lain-lain untuk menambah atraksi baru.

3. Pengembangan desa wisata di sekitar Ngarai Sianok diarahkan untuk meningkatkan nilai jual wisata sehingga bisa menjadi alternatif atau referensi baru untuk dikunjungi wisatawan mancanegara.

\section{Keterbatasan Penelitian}

Keterbatasan penelitian ini adalah sulitnya menemukan wisatawan yang mau menjadi informan, hal ini dikarenakan kebanyakan wisatawan tidak ingin diganggu pada saat sedang berwisata.

Keterbatasan yang berikutnya adalah terkait dengan proses pengumpulan data dimana penulis mengumpulkan data melalui informan yang bersedia diwawancara dengan waktu yang relatif singkat. Hasil wawancara kemudian diolah sedemikian rupa agar dapat dianalisa dalam penelitian ini.

\section{DAFTAR PUSTAKA}

Damanik, J., 2013, Pariwisata Indonesia Antara Peluang dan Tantangan. Yogyakarta: Pusaka Pelajar.

Dharmnesta, B. S., dan Handoko, T., 1982, Manajemen Pemasaran Analisis Perilaku Konsumen. Yogyakarta: BPFE.

Moleong, L. J.,2012, Metodologi Penelitian Kualitatif Edisi Revisi. Bandung: PT Remaja Rosdakarya Offset.

Pitana, I Gde., dan Gayatri., 2005, Sosiologi Pariwisata. Yogyakarta: Andi Offset.

Pratminingsih., Rudatin., dan Rimenta., 2014, Roles of Motivation and Destination Image in Predicting Tourist Revisit Intention: A Case of Bandung - Indonesia. International Journal of Innovation, Management and Technology, Vol. 5, No. 1: 19-24.

Rajesh, R., 2013, Impact of Tourist Perceptions, Destination Image and Tourist Satisfaction on Destination Loyalty. Pondicherry University. Puducherry: India. A Conceptual Model, Vol. 11, No. 3: 67-78.

Suwantoro, Gamal., 2004, Dasar-dasar Pariwisata. Yogyakarta. Andi

Sawirman., dan Emrizal., 2008, Bisnis Pariwisata Sumatera Barat Sebuah Analisis SWOT. Jurnal Ekonomi dan Bisnis, Vol. 3, No. 2: 164171. 